\title{
ПРОБЛЕМИ НАВЧАННЯ ТА ВИХОВАННЯ У СУЧАСНІЙ ШКОЛІ
}

\begin{abstract}
Сагуйченко В. В.
доктор філософських наук, професор, професор кафедри філософії Комунальний заклад вищої освіти КВНЗ «Дніпровська академія неперервної освіти» ДОР», м. Дніпро, Україна
\end{abstract}

Автором, виходячи із визначення школи як життєвого світу учнів та вчителів, пропонується для успішного практичного впровадження Конщепиї̈ реформування навчання та виховання, заручитися широкою суспільною підтримкою освітніх змін для розвитку інноваційних процесів у всіх сферах життя краӥни.

Ключові слова: реформи, інновачії, освіта, навчання, виховання.

The author, based on the definition of school as a life world of students and teachers, proposes for the successful practical implementation of the Concept of reforming teaching and education, to gain broad public support for educational change for the development of innovation processes in all spheres of the country.

Key words: reforms, innovations, education, training, upbringing.

Працюючи над проблемами дослідження реформування освіти, визначаючи теоретико-методологічне обгрунтування цього складного процесу, розуміємо, — віддача від виховної і навчальної діяльності неможлива без розуміння і підтримки державної освітньої політики у суспільстві [2]. Значна роль у цьому процесі належить знанню та дотриманню нормативно-правової бази в галузі освіти, як працівниками освіти так і громадськістю. Від здібності всіх суб'єктів навчально-виховного процесу сприймати нове, налаштовувати себе до інноваційної діяльності залежить траєкторія руху закладу до демократичної освіти. Характеризуючи це відчуття нового, відзначаємо його — як здатність бачити перспективу розвитку, здібність заглядати у майбутнє, знаходити найбільш вірні шляхи до рішення виникаючих проблем. Разом 3 цим, це визначає здібності цілеспрямовано долати все застаріле, йти на розумний ризик, експеримент заради утвердження нового, передового, інноваційного.

Покращення процесів навчання та виховання складається із спільної роботи закладів освіти, сім’ї та громадськості за єдиною державною 
Розділ І. Ціннісні орієнтири духовно-інтелектуального виховання, розвиток духовно-інтелектуальних якостей особистості в умовах співпраці й інклюзії

освітньою політикою з врахуванням місцевих та регіональних особливостей і відмінностей. Важливість підтримки освітніх змін різними верстами суспільства вимагає залучення до співпраці батьків, учнів, громадськості, спонсорів, меценатів, людей бізнесу та влади. Важливо навчити всіх учасників навчально-виховного процесу брати участь у формуванні цілей, завдань, планів та стратегій розвитку загальноосвітніх навчальних закладів; суті, принципів, цілепокладання державної політики; ознак, відмінностей і етапів впровадження та управління державною освітньою політикою в Україні та країнах світу; стимулювання постійної самоосвітньої діяльності, підвищення мотивації до саморозвитку та самореалізації всіх учасників освітнього процесу в умовах сучасних змін; ознайомлення педагогів із сучасними інтерактивними формами і методами педагогіки продуктивного навчання, специфікою педагогічного, учнівського та батьківського самоврядування; оснащення основними сучасними ключовими політичними та соціальними компетенція ми, зокрема такими як: здатність брати участь у виробленні групових рішень, спроможність вирішувати конфлікти ненасильницькими засобами, готовність брати участь у підтримці і покращенні демократичних інституцій; залучення до проектної діяльності, до практичного партнерства в освіті [1; 3].

Це дає у подальшому сподіватися на впровадження державно-громадського управління в практику роботи загальноосвітніх навчальних закладів; свідомий вибір форм і моделей управління освітою; широка підтримка освітніх реформ та державної політики країни

Подальших досліджень потребує розробка нових підходів до мотивації, проектування, організації та подальшого впровадження громадських складових у державно-громадському управлінні загальноосвітнього навчального закладу. Сподіваючись на досягнення у вихованні та навчанні, необхідно зосередитися на вирішенні наступних завдань: роз'яснення широкому колу громадськості суті державної освітньої політики, розкриття потенціалу громадських організацій через надання їм високоякісних освітніх, консультаційних та інформаційних послуг, поширення спільної продуктивної діяльності між освітніми навчальними закладами, органами влади, бізнесом та іншими структурами громадянського суспільства, розвиток та зміцнення місцевої громади через сприяння освітнім громадським ініціативам, що орієнтовані на якісний результат спільної діяльності школи та громад- 
ськості, розробка та участь у власних освітніх та соціальних проектах, дослідження громадської думки щодо реформування сучасної освіти та соціальних процесів, підтримки освітніх та соціальних проектів у регіоні, залучення громадських організацій та фахівців до розробки пропозицій щодо удосконалення нормативно-правової бази спільної діяльності в освітній сфері на місцевому рівні, участь у програмах культурного обміну, видання друкованих та електронних інформаційних матеріалів для місцевих громад, неурядових організацій, лідерів та активістів громадського руху з питань освітньої політики в регіоні, державі, країнах Європейської співдружності та інших країнах світу, залучення до партнерства всіх бажаючих працювати над удосконаленням навчання та виховання, в тому числі, органів батьківського самоврядування, голів піклувальних та шкільних рад, представників місцевих громад, учнівського самоврядування, владних, бізнесових структур, релігійних конфесій та національних меншин.

\section{Список використаних джерел:}

1. Сагуйченко В.В. Соціальне партнерство як платформа підтримки освітніх реформ. Суми : ПФ «Видавництво «Університетська книга»», 2021. $104 \mathrm{c}$.

2. Сагуйченко В.В. Трансформація освіти: виклики та ризики реформування : монографія. Суми : ПФ «Видавництво «Університетська книга»», 2020. $478 \mathrm{c}$.

3. Sahuichenko V. Postgraduate pedagogical education: trends and risks // Revista Dilemas Contemporáneos: Educación, Política y Valores, Vol. Year VI, No. Special Edition, August 2019, 2019. pp. Artículo no. 1; pp. 1-17. 